\section{THE WORK OF THE ROYAL FREE HOSPITAL UNIT IN SERBIA.*}

\section{BY JAMES BERRY, F.R.C.S. ENG.}

As the summer wore on and the long-expected renewal of active hostilities on the Serbian frontier did not take place the number of patients in our hospitals at Vrnjatchka Banja gradually diminished. On August 9th the total number of in-patients was but 180, on Sept. 8th only 167, and of these about one-tenth were civilians. On July 27th a meeting of the heads of the British units then in Serbia had been summoned at Kragujevatz to discuss the situation with Sir Ralph Paget, the British Commissioner. It was then unanimously agreed that the units should stay in Serbia at least a few weeks longer. Our own unit had already received a letter from the Commander-in-Chief (Genera] Putnik), begging us to remain in Serbia. Later, a circular letter from the Crown Prince was sent to all the units, expressing the hope that the day of their departure would be far distant. It was clear that the horrors of the previous winter, due largely to the lack of doctors, nurses, and sanitary material of all kinds, were still fresh in the minds of the Serbian authorities. They were anxious that we should stay as long as possible with them. In the meantime, although not overburdened with work, we found enough to do with general sanitation and with out-patients.

All through the summer our civilian out-patient department was large, men, women, and children coming often from far-distant villages to receive the advice and medicine bestowed upon them chiefly by Dr. Helen Boyle, Dr. Ada McLaren, Dr. Isabel Inglis, and others, who did admirable work in this sphere of usefulness. The most striking feature of this civilian practice was the great prevalence of all forms of tuberculosis and of diphtheria. The inveterate Serbian custom of living in stuffy, overheated, and ill-ventilated rooms-a custom by no means limited to the poorer classesis donbtless responsible for the ravages of tubercle in this unfortunate country. The insanitary conditions found in and around most Serbian cottages accounted fully for the prevalence of diphtheria.

Some of the younger patients whom for various reasons we admitted to our wards vomited or passed per anum as many as 50 round worms; nearly every child had at least one round worm. Tapeworms we saw but seldom. The extraordinary prevalence of round worms among both children and adults is doubtless explained by the open and polluted springs and wells from which the vast majority of the rural population obtain their drinking-water.

\section{Renerval of Active Hostilities.}

Towards the end of September came the news of Bulgaria's mobilisation. All passenger traffic on the railways was stopped. Some of us who were at Nish at that time saw thousands of troops with. guns and stores of all kinds being rushed through to the Bulgarian frontier. At Vrnjatchka Banja day and night troop-trains could be heard running down our valley of the Western Morava on their way to the Eastern front. On Sept. 30th a small party of us had occasion to go to Kragujevatz, the military headquarters and seat of the Arsenal. We arrived just in time to see the end of an Austro-German aeroplane raid. Wild excitement prevailed. A German aeroplane had just been brought down in the centre of the town and all Kragujevatz was jubilant. The mangled and scorched bodies of the unfortunate airmen brought home to us very vividly the horrors of war. The remains of the aeroplane, which we inspected at the arsenal, showed the

* The official name of the unit was Anglo-Serbian Hospital, but in Serbia it was known as the Berry Mission, having been organised by Mr. James Berry and Mrs. Berry, M.D., who appointed a small committee to continue their work of collecting funds during their absence. As many members of the medical and nursing staff an committee were associated with the Royal Free Hospital, which belped the mission in other ways, we give the name which it usually received. - ED. I

I See The LanckT, Jan. 29th, 1916, p. 270.

The name of our village or little town is Vrntse. As Serbian proper names are always declined, the Baths of Vrntse are I'rnjatchka Banja, just as one might speak of Harrogate and "Harrogatian" Baths, if similar practice prevailed here. Another and formerly better-know place in Serbia, much furtber south, is Vranje; this also has baths, called Vranshka Banja. There was much confusion of all these names, even by members of the English missions. name of a Stuttgart maker. Early on the following morning we were roused by the sound of fresh firing, and were interested spectators of another air raid in which many bombs were dropped, several civilians and one Austrian prisoner being killed. One bomb fell without exploding in the soft ground of the Stobart camp, at which we were staying, and another did much damage to their stock of marmalade, and, by a few feet, just missed killing a nurse. The object of the raid was evidently the arsenal, into which two or three bombs were actually dropped. A Serb workman was killed, and a couple of bullets penetrated a large petrol tank, but otherwise no harm was done. A good account of this raid has been published by our engineer, Mr. Jan Gordon, ${ }^{3}$ who was himself in the arsenal with our motor-car when the bombs fell.

On Oct. 8th a visit to Nish showed the town gaily decorated with flags in excited anticipation of the arrival of French troops who were expected from Salonica on the morrow, but who never came. Crowds of refugees were coming in from Posharevatz, which had just been heavily bombarded from the air. No one seemed to know whether the line from Salonica was still open or not. Among the officials, both Serb and foreign, pessimism was very marked, and not a few indignant remarks were heard about the Allies who had "deserted" Serbia in her time of need. There was among the people, and to a certain extent among the officials, a strong feeling that Serbia, who in the earlier stages of the war had done so much for the allied cause, by decisive victories over the Austrians, should not have been left singlehanded to repel a simultaneous invasion by three nations. Although necessarily ignorant of the military reasons which forbade the granting of much-needed help to the sorely tried little nation, we could not help wondering whether these criticisms were not perhaps to some extent justified.

On Oct. 8th the British Commissioner informed us that it was the wish of the Serbian military authorities that the British units should withdraw if the Serbian army found it necessary to retreat, as it was expected they would. By so doing it was hoped that their personnel and stores would be preserved for future service, and they would obviously be of more service both to Serbia and to the allied cause than if they stayed on and became prisoners. They were to hold themselves in readiness to take this step when the expected military orders to this effect arrived, which, however, in our case they never did.

\section{Arrival of Wounded.}

Two days later, freshly wounded began to dribble into our hospitals and we heard tales of severe fighting on the northern frontier. But it was not until the 17th that we received a large batch of severely wounded. Among them were several perforating wounds of the brain and numerous compound fractures of the thigh. All wounds had been inflicted at least two or three days previously and most were already septic. We were struck nevertheless by the care that had been taken in the preliminary dressing and splinting of the patients. Nearly all had been caused by shrapnel bullet, a few by rifle-fire, scarcely any by bayonet. An extensive wound of the frontal lobe with much loss of brain substance was treated by being laid freely open, nearly half the left frontal bone having to be removed with trephine and forceps; a large hernia cerebri ensued, but this gradually receded and in a few weeks the patient made a good recovery and seemed but little the worse for his injury. Another, with a depressed but nonperforating shrapnel wound of the right occipital lobe, was on admission completely blind in both eyes; the depressed bone was removed. About three days later he had recovered his sight so far that he could distinguish and name coins shown to him, and was doing very well indeed. Two days later he suddenly complained of violent pains in the head and died in a few hours. Another man, under the care of $m y$ colleague, Dr. J. B. Christopherson at the Drzhavna Hospital, had been shot through the centre of the head of the left humerus; a conical German bullet was extracted from the lower part of the right axilla in the mid-axillary line. The patient made an excellent and speedy recovery, but how the great vessels of the mediastinum escaped injury is difficult to explain. Another man was shot transversely through the centre of the thorax, the bullet passing between

3 In his entertaining little book, "The Luck of Thirteen." Smith, Elder, and Co. 1916. 
FIG. 1.

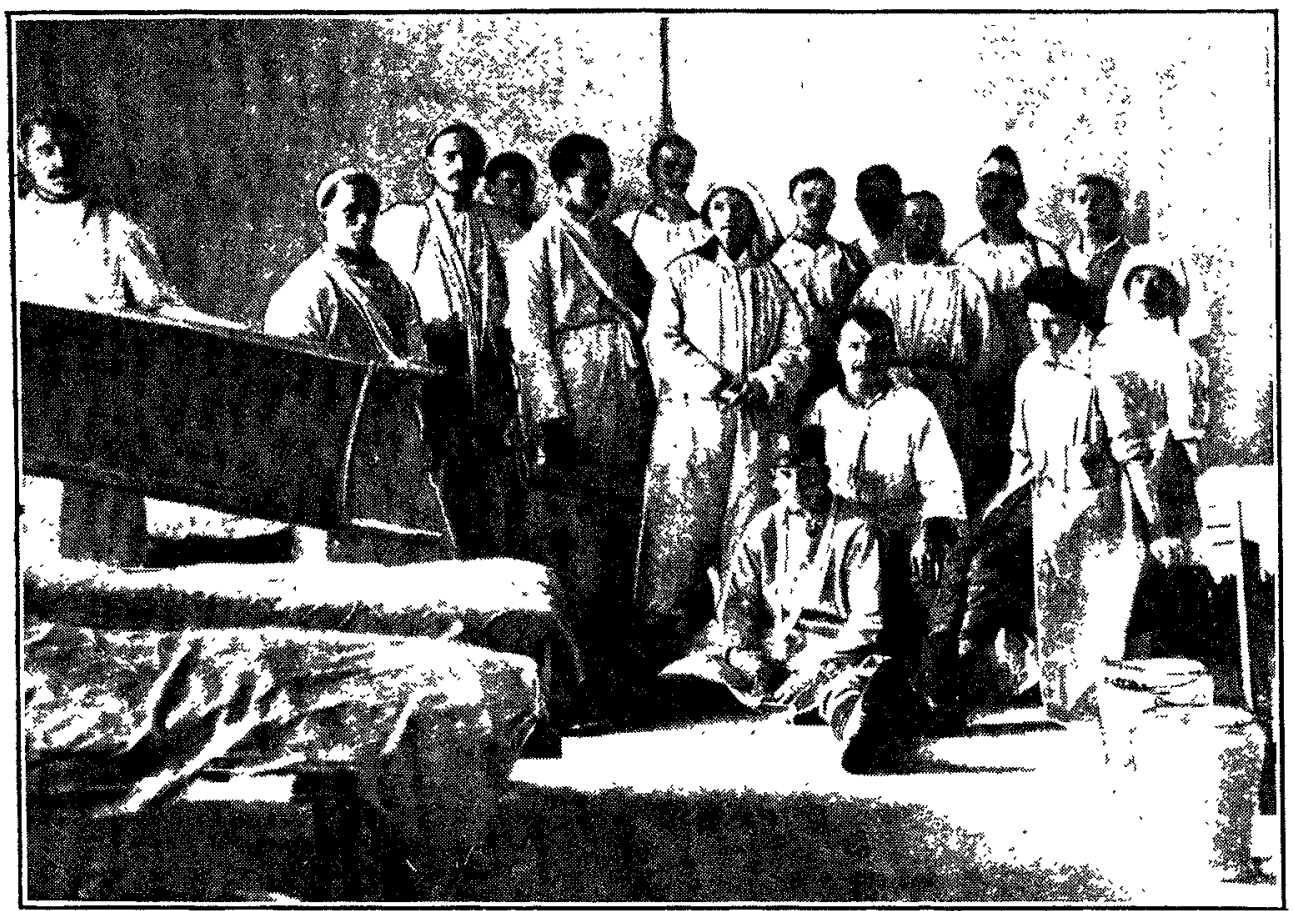

Receiving room at the "Terapia" hospital. English nurses with English and Austrian orderlies Each patient arrived through the window (on the left) and was dressed. shaved, washed, and provided with clean hospital garments before being taken to the ward. By these means all lice and nits were removed before the patient came into the warls, and typhus, although often introduced, never spread to other patients.

the cesophagus and the heart; a left empyema developed. For a time the patient was very ill, but seemed to be on the high road to recovery, when he was transferred to another hospital and we lost sight of him.

On the 15th news came that the Austrians were occupying Posharevatz, Semendria, Belgrade, and Obrenovatz. Also that the Bulgars had penetrated the Eastern frontier at two points, although it was rumoured that they had been driven back again. Major Gashitch, our energetic and esteemed Serb medical director, warned us that we might receive orders to move at very short notice. Packing-cases were brought out by our engineer and made ready for immediate use.

From Oct. 16th till the 18th Vrntse was full of rumours War on Bulgaria had been declared by the Great Powers, Varna and Bourgas were being bombarded by the Russians, Strumnitza had been occupied by the French, Tsaribrod by the Serbs, the National Bank had been transferred to Prisrend and the military headquarters to Krushevatz. A strange jumble of truth and fiction, but at the time we had no means of separating the one from the other.

On the 21st a large number of slightly wounded arrived, and as the train which brought them had many severely wounded on board, who went on to the Serb hospital at Chachak, we were indignant at what seemed to us a breach of faith on the part of the military authorities. For months before, when entreated by the Serb military authorities to prolong our stay in Serbia, we had been repeatedly assured, both verbally and in writing. that when fresh fighting began only the most severe surgical cases would be sent to us. On pressing the major for an explanation, we learnt that a secret order had been received that for the present only slightly wounded were to be sent to the foreign missions, as an order for their withdrawal to the south was to be expected at any moment.

On the 27th another trainload of wounded, mostly not very severe cases, arrived, and we were all kept busy. On the 28th important news arrived. Cyhitsa, to the west, at the head of our valley, was being evacuated, and all British missions to the north of us were being withdram to the line of the Western Morava; our little town lay some three miles south of this, between Kraljevo and Krushevatz. Kragujevatz, 50 miles (by road) to the north, was being evacuated the head-quarters staff moving thence to Krushevatz. The seat of government was being trans. ferred to Kraljevo. About this time officials of the public health and some other departments, together with many ex-ministers, sought refuge at Vrnjatchka Banja, the fashionable health resort of Serbia. The place began to be inconveniently over. crowded, and we began to fear shortage of food. The 2nd British Farmers' unit under Mr. Parsons, the Scottish Women's unit under Dr. Alice Hutchison, and several members of the Wounded Allies' Mission under Dr Apsland arrived, and con. siderable rearrangement of our hospitals took place. The Farmers, who had been obliged to leave Belgrade very hurriedly during the bombardment, took over our Merkur Hospital and the Scottish Women for a short time had the Atina:

\section{A Difficult Situation.}

The British Commissioner now paid us a hurried visit to explain the arrangements he had been trying to make with the Serbian authorities for the withdrawal of the British units to the south or west. Only a very few ox-wagons were obtainable, and it was obvious that most of the units at Vrnjatchka Banja would have to stay and be captured; only individual members, who for one reason or another desired to escape, would have the opportunity of making their way mostly on foot across the mountains to the Adriatic. Three of our unit, together with several of the British Red Cross unit (mostly English orderlies), went off together under the leadership of Mr. Gordon. The adventures and trials which they met with on their difficult trek to S. Giovanni di Medua, have been graphically told by Mr. and Mrs. Gordon in their Fig. 2.

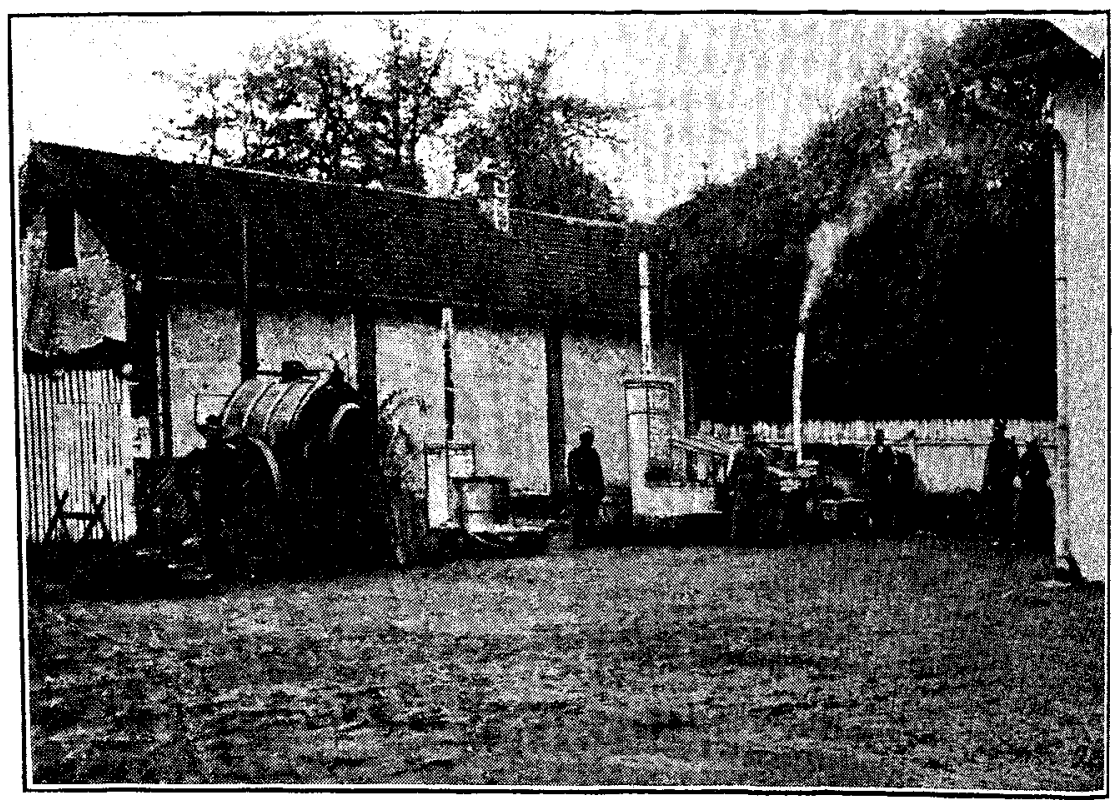

The yard of the "Drzhavna" hospital, showing (right to left) hot-water boiler, destructor for dirty dressings and other refuse, tank for boiling infected clothing, and a "Thresh" disinfector recently arrived (September, 1915) from England. The tanks were made by the local tinsmith, and the brickwork built by Austrian orderlies. (From a photograph by my colleague, Dr. J. B. Christopherson.) 
book, already mentioned. The numbers of our unit remained, however, at the average strength of 25 , having been reinforced by the addition of the British chaplain and two refugee ladies from Belgrade and Nish.

On Nov. 1st all the Austrian prisoners except four were withdrawn from our hospitals and replaced by 16 Serbian youths with no personal knowledge whatever of hospital work. On the same day our Serbian military head, although giving no direct order, strongly advised us to withdraw also, abandoning all our stores and personal luggage. Dr. Charles Mack, an American doctor, kindly consented to take charge of the hospital if we decided to do so, and the great majority of our members were anxious to go. We knew of direct short route across the mountains to Rashka, a place which Mrs. Berry and I had visited many years before, and thence it would have been possible to get across viâ Novi Bazar and Berane to the Adriatic. But this would have meant walking the whole way, carrying provisions for at least a fortnight. For this it was essential we should have at least three or four horses to carry food and blankets. We were quite determined not to attempt the ordinary route viâ Kraljevo and the long, narrow Ibar gorge, which was also known to us, as it was the main route by which the Serb army was retreating. and was likely to be choked by refugees. Our hesitation, which lasted for a few hours, was ended when we found that the horses we had expected to obtain were not available.

On the following day all our Austrian prisoners were restored to us, and the contingent of Serbian youths, who in the meantime had been washed and cleared of lice, in their turn withdrew.

A week of considerable anxiety ensued. Again nearly all the Austrian prisoners were taken away, a few only, who desired to remain with us, being allowed to do so. They made their way over the mountains in front of the retreating Serbian army, and we fear that many must have perished in the severe cold that set in some ten days later. Day by day the sound of distant cannonade became louder and londer as the Austro-German forces approached. Rumour said that a stand would be made in our valley at Trstenik, a narrow place some three miles to the east of us. It was said that the digging of trenches had actually begun. It seemed probable that we should find ourselves in the very centre of a battle. Late in the evening of the 6th a violent explosion, which shook the building, caused some of us to exclaim, "Here is the first shell!" But it was caused by our own people blowing up the great bridge of Trstenik. Our Serb commissaire at the Terapia had sought safety in flight, but the Austro-Serbian one at the Drzhavna, M. Milutin Jovanovitch, remained with us and rendered invaluable service. Our wood-supply gave out, and as no more was forthcoming we began cutting down the trees in the grounds of the Terapia.

\section{Entry of the Enemy.}

Early on Nov. 10th a Hungarian lieutenant with half a dozen soldiers arrived, went all over the hospital, asked for a complete list of our personnel, paid us a few compliments on the state of our hospital, put an armed sentry at the gate and departed. In the next few days we had numerous Austro-Hnngarian visitors at the hospitals - generals, colonels, a count, and finally Prince Lobkovitz, who took command of the whole district. Colonel Dr. Pick was in charge of all the medical arrangements, and his first act was to confirm the appointment of the heads of our unit, saying he did not wish to interfere in any way with our management of the hospitals and giving us the necessary Austrian authority to continue our hospital work under his nominal supervision. He consulted freely with us and Major Gashitch as to the best means of rearranging the medical work at Vrnjatchka Banja. The Atina was given over for a short time to another English unit, our baraque was evacuated and then the school, the latter being quickly filled with crowds of frost-bitten Hungarians returning from the mountains, very severe cold having set in on the 17th. Our own hospitals were now reduced to two, the Terapia and the Drzhavna. Both were overcrowded with Serb wounded; at the former patients overflowed into the corridors, where we put them on improvised tresile-beds and mattresses. The evacuation of the slighter cases was then rapidly carried out, and as frost-bitten Hungarians continued to pour into the town we were asked to admit some of them for whom no other accommodation could be found. This we naturally consented to do. The Medical Director-General of the Austrians in Serbia
FIG. 3.

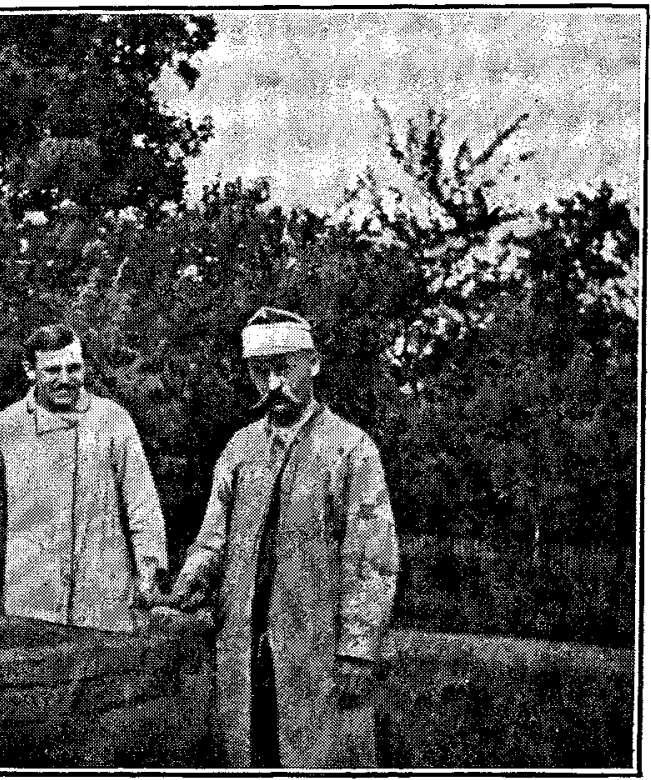
visited us, and I overheard him telling another officer that all members of the missions would be interned until the end of the war. This was clearly a contravention of the Geneva Convention, and in all discussions with the Austrians on this subject continued to point this out. We were much surprised to find how little was known of this Convention by all the Austro-Hungarians with whom we came into contact. The best informed was Captain Dr. Otto Panczél, an elderly Hungarian, who before the war had practised as a civilian surgeon at Pancsova and who became our medical commandant after Colonel Pick's departure. To his courtesy, practical good sense, and kindly feeling towards us we were much indebted during our three months under his charge. I cannot refrain from relating an incident which illustrates the curious ideas about English government which are prevalent even among intelligent and well-informed Hungarians. After a long conversation one day with him on the subject of the politics and history of Hungary, he said suddenly, "Well, you English treat your colonies so badly!" "How so ?" said I. "Well, you do not allow them to buy or sell except with the mother country," was his answer, and nothing that I could say would move him from his fixed belief that such were the trade relations between England and her colonies. Equally surprising ignorance about circumstances nearer home was displayed by another Hungarian doctor of good family and education, who made to me the common but ridiculous assertion that "the Serbs had killed the Austrian Archduke." He seemed much interested and surprised to learn that Cabrinovitch Prinzip and the other assassins were Austrian Slav subjects and not Serbs as the Austrians endeavour to make the world believe.

With regard to food, we fared, on the whole, fairly well. The Austrians allowed us daily rations, which included a little meat; bread varied in quantity from half a loaf per head when it was abundant to one-fifth when it was scarce, as it often was. Besides these we had small quantities of tea, coffee, sugar, and lard, and various other things. A scale of prices was arranged and the peasants were obliged to bring eggs, milk, and other provisions to a central office, whence they were distributed among Austrians, English, and Serbs. Had we been wholly dependent upon the Austrian rations we should have fared 
barly, but fortunately our own food stores were by no means testing of vision. In the course of the year more than exhausted and we had laid in a considerable stock of flour, rice, and live poultry before the invaders arrived. With these stores the enemy never interfered although they occasionally threatened to do so.

On Feb. 18th we were allowed to depart under the charge of a couple of Hungarian guards, who however, behaved towards us rather as couriers than as gaolers, and treated us with the greatest friendliness and courtesy. We travelled vî̂ Belgrade, Budapest, and Vienna, to Bludenz on the Swiss frontier, where we were detained nine days, to ensure that any military news that we might bring from Serbia should be stale. We reached Zürich on March 2ad, and thence came home viâ Pontarlier and Paris, the French military authorities giving us free passes through France and treating us with the utmost respect and courtesy.

\section{REPORT OF THE COUNTY MEDICAL OFFICER OF HEALTH AND SCHOOL MEDICAL OFFICER OF LONDON FOR 1914.}

(Concluded from p. 834.)

\section{Part II.-Education.}

APPRECIATIVE reference has frequently been made in these columns to the coördination of the Public Health and Education Departments which was achieved by the London County Council in 1911. The experience of another complete year as to the working of the new system is now available.

In the course of the year 1913 inquiry was made by the Board of Education into the operation of the Council's scheme of medical inspection and treatment. In a letter reproduced in the medical officer's report for that year the Board suggested some modifications of the scheme. On certain important points, however, the Council's reply had not been agreed upon in time to allow of its appearance in the report for 1913, then almost ready for press. The reply will, however, be found in full at pp. 83-5 of the present volume. The question of the medical staff, as regards its numerical strength, duties, and permanency, was already engaging the Council's attention at the date of receipt of the 'Board's letter. As a result the duties of the assistant school inspectors have been rearranged, so that their services are now utilised for the whole field of public health work. Moreover, the organising staff has been increased, a definite proportion of its members being allocated to the Public Health Department. Additional facilities for nursing treatment have also been secured, and arrangements have been made that the doctor in charge should be satisfactorily informed respecting the antecedents of children presented for treatment

In spite of unforeseen difficulties due to war conditions, by which progress has in some degree been retarded, it is encouraging to realise that the arrangements above specified are already in actual operation. On the other hand, considerable disturbance of staff routine has unavoidably taken place. In the treatment centres and hospitals many changes of personnel have occurred, thus interfering to some extent with continuity of method. Owing to the absence on military duty of the permanent school doctor, it has at times been necessary to carry on the work with the aid of temporary substitutes. Inconvenience has also arisen from inevitable changes in the nursing staff. In these circumstances it will be necessary to await the return of normal conditions before a reliable estimate can be formed of the value of the rearrangements hitherto effected.

\section{Medioal Inspection of Sohool Children.}

In the earlier months of 1914 the work of inspection was carried out, in accordance with the suggestions of the Board of Education, by 35 assistant medical officers under the direction of 5 divisional chiefs. On the outbreak of war several of these officers were called up for military duty, their places being generally filled by medical practitioners devoting part of their time to the work This inspecting staff was assisted by 106 certificated nurses, who prepared the children for examination and helped in the weighing and measuring processes and in the
294,000 children were medically examined, and of these about one-third wore found to need treatment. Comparing the results of this examination with those of the two pre ceding years a gratifying amendment was observed. Steady improvement in cleanliness and neatness was manifest reflecting great credit on the school nurses, the head teachers, and the workers of the Care Committee. In accordance with the regulations of the Board of Education examination is required of all entrants and leavers, and in addition an intermediate group of children aged 8-9 years are regularly examined. Consequently there are now three sets of complete records, and the results of inspection in the several years can be readily compared. The term "entrant" is limited to infants under 6, the term "leaver" to children of 12 years and upwards. At the time of inspection the mother is invited to be present. A representative of the Care Committee is likewise asked to attend in order to secure that each child shall receive the medical treatment prescribed. Experience proves that, although starting schoollife on an equality with boys, the girls on leaving show excessive tendency to defects of eye and heart, as well as a greater liability to anæmia and to nervous diseases. These facts suggest that girls for the most part lead a less healthy home-life than their brothers. At the time of medical inspection the height and weight of children are recorded. They are classified as to condition of clothing, state of nutrition, cleanliness of head and body, and state of teeth. The averages are said to be very constant. It is noteworthy that entrants are generally cleaner than older children, but that girls, in con. sequence of wearing long hair, more frequently suffer from dirty and verminous heads than boys. In regard to cleanli. ness of body, however, the girls appear to advantage. The record of steady improvement during the three years as regards the cleanliness of the children and the sufficiency of their clothing is the most encouraging feature of these inspections. Although it is to be deplored that even now the heads of only 67 per cent. of the girls are completely free from traces of vermin, it must be remembered that ten years ago instead of 67 per cent. being clean, in those days over 67 per cent. were verminous.

Adenoids and enlarged tonsils. - The proportion of children now found thus affected is less than formerly. The reduction is greatest at the higher ages, a fact which may be accepted as an indication that present facilities for treat. ment are playing an important part in improving the health of school children.

Enlarged glands of the neck.-Considerable improvement is reported under this head also. The percentage of children thus ailing fell from 10.5 in 1913 to 8.8 in the recent year, and only 1 in 20 of these was considered sufficiently ill to require operative interference.

Disease of thyroid gland.-Considerable attention has lately been directed to abnormalities of this gland, especially in those cases in which there exists deficiency of secretion, leading to retardation of mental and bodily growth, and even to idiotcy. The effects of over-action of the gland in adults, constituting exophthalmic goitre, are-well known, but to the beginnings of this condition in children little atten. tion has hitherto been paid. Dr. Louis Leipoldt, a former member of the staff, has carefully investigated this question. Out of 5000 children examined he found 52 cases in which symptoms of this over-action were detected. Of these 52 children not fewer than 42 presented definite evidence of septic absorption, either from carious teeth, otorrhoea, or inflamed tonsils. He refers to the striking improvement effected by dental treatment in certain of these cases-the thyroid enlargement disappeared and the usual nervous symptoms abated. Dr. Leipoldt's investigations show that undetected septic conditions in childhood sometimes produce far-reaching ill-effects. They furnish additional reasons for inducing parents to obtain treatment for all children found defective in this respect.

\section{Medical and Dental Treatment.}

During the last three years the facilities provided in London for the medical treatment of school children have been materially increased. For all classes of ailment treated under the Council's scheme the "centres," including hos pitals, at the end of the year numbered 42, providing for 98,976 children, as against 34 centres for 84,359 children at the end of 1913. Owing chiefly to the great demand 